\title{
Succeeding Against Odds, Courting Collapse: How Mitsubishi Shipbuilding and Kawasaki Dockyard Managed the Post-WWI Slump
}

\author{
By Takao Shiba \\ Kyoto Sangyo University
}

\section{Introduction}

The dozen years after the end of World War I saw Japan's shipbuilding industry facing a severe depression. During the war, the industry had expanded enormously by taking advantage of the boom in the shipping industry. With the end of the war, the boom collapsed, and shippers sharply curtailed orders for new vessels. Then, in 1922, conclusion of the Washington Disarmament Agreement abruptly reduced orders from the Japanese Navy as well. There was a brief period of prosperity at the end of the 1920's, but the start of the 1930's saw Japan's shipbuilders facing their worst business environment ever. It was only in 1932, when the Japanese government adopted a shipbuilding promotion policy, that the industry recovered. The basic thrust of the government's Ship-Improvement Subsidy Measure was to aid shipbuilders indirectly, by paying subsidies to ship operators who would junk old ships and order new ones.

During the period under discussion, Japan's two biggest shipbuilding firms were Mitsubishi Zosen Kabushiki Kaisha (Mitsubishi Shipbuilding and Engineering Company) and Kawasaki Zosen Sho (Kawasaki Dockyard Company). Both suffered from the same depressed business conditions as their rivals in the industry, but Kawasaki was damaged much more severely. In 1927 it nearly failed. Then, following a short period in which it seemed to recover, it fell into a worse situation. In contrast, Mitsubishi's performance worsened steadily as the depression deepened, until in 1932 its accounts for the first half of the fiscal year went into the red for the first time in the company's history. This was, however, the first as well as the last time the company posted a deficit: a clear demonstration of its relative strength in the shipbuilding industry. If we examine the causes for this difference, we find that while Mitsubishi pursued a cautious policy that conserved the resources it needed to overcome the depression, Kawasaki's strategy was aggressive. A program of rapid expansion despite a hostile business climate plunged the company into deeper and deeper financial trouble. 
This picture emerges clearly if we look closely at the early years of the 1920's when differences between the two companies became ap. parent. This paper intends to demonstrate it.

\section{Business Performance Following WWI}

Table 1 shows the drastic decline in business volume that Japan's shipbuilding industry suffered during the period from the end of World War I to the middle of the 1920's. In 1919, Japan's seven largest shipbuilders produced vessels totaling 474,000 gross tons. By 1925 that figure fell to 43,000 gross tons, just $9.1 \%$ of what it had been six years earlier. Mitsubishi, however, suffered less than other builders. Orders declined rapidly after 1921 but remained within $20-30 \%$ of their level in 1919. The company's market share expanded from $13 \%$ in 1919 , and it captured $30-40 \%$ of the market every year except 1924 .

In contrast to Mitsubishi, Kawasaki's position in the merchant ship market was extremely weak. True, despite an overall decline in orders, the company was able to launch more than one ship in every year except

Table 1 Ships Built by Japan's Seven Major Shipbuilders, Mitsubishi and Kawasaki

\begin{tabular}{lrrrrrrr}
\multicolumn{1}{l}{ Seven Majors } & \multicolumn{2}{l}{ Mitsubishi } & \multicolumn{2}{c}{ Kawasaki } \\
1919 & $(90)$ & 474,305 & $(10)$ & $61,816[13.0]$ & $(35)$ & $196,572[41.4]$ \\
1920 & $(65)$ & 328,471 & $(11)$ & $64,314[19.6]$ & $(13)$ & $76,331[23.3]$ \\
1921 & $(33)$ & 183,464 & $(6)$ & $44,449[24.2]$ & $(7)$ & $45,324[24.7]$ \\
1922 & $(15)$ & 59,428 & $(3)$ & $17,651[29.7]$ & $(2)$ & $13,162[22.1]$ \\
1923 & $(16)$ & 50,892 & $(5)$ & $20,747[40.8]$ & $(1)$ & $6,566[12.9]$ \\
1924 & $(16)$ & 52,697 & $(2)$ & $6,917[13.1]$ & $(1)$ & $5,832[11.1]$ \\
1925 & $(14)$ & 43,889 & $(3)$ & $18,282[41.7]$ & & - \\
1926 & $(13)$ & 44,701 & $(4)$ & $13,061[29.2]$ & $(1)$ & $5,950[13.3]$ \\
1927 & $(13)$ & 46,120 & $(4)$ & $20,810[45.1]$ & & - \\
1928 & $(22)$ & 101,809 & $(8)$ & $50,908[50.0]$ & & - \\
1929 & $(26)$ & 157,410 & $(6)$ & $58,123[36.9]$ & $(2)$ & $2,826[1.8]$ \\
1930 & $(23)$ & 143,206 & $(7)$ & $56,768[39.7]$ & $(4)$ & $13,032[9.1]$ \\
1931 & $(15)$ & 78,749 & $(4)$ & $19,624[24.9]$ & $(1)$ & $5,959[7.6]$
\end{tabular}

Notes: 1) Only ships over 1,000 gross tons are taken into account. 2) The seven majors include Mitsubishi Zosen, Yokohama Dock, Mitsui Bussan Zosenbu, Osaka Tekko Sho, Harima Zosen Sho, Kawasaki Zosen Sho and Uraga Dock. 3) Figures in parentheses are numbers of ships and those in brackets are market share in relation to the seven majors.

Source: Company histories of each firm; Nihon Kinsei Zosenshi: Taisho Jidai (The Modern History of Japanese Shipbuilding: Taisho Era), Zosen Kyokai, 1935; Honpo Kenzosen Yamokuhyo (The List of Ships Built in Japan), Kaibundo, 1976. 
1925 , but this statistic is somewhat misleading. If we look at the customers for its ships, we find that the biggest factor affecting the company's business was the type of transaction its business involved.

As shown in Table 2, nearly $90 \%$ of the ships Kawasaki built from 1919 to 1926 were ordered for its own expansion into ship operation. Orders from unaffiliated firms accounted for only $10 \%$ of its total business. Further, even these customers were not ordinary commercial shipping firms. Some orders were placed by the United States government, following the wartime agreement on exchange of steel for ships between the United States and Japan. ${ }^{1)}$ There was one order from Kawasaki Kisen, but this firm was itself a wholly owned subsidiary of Kawasaki Dockyard. $^{2)}$ Thus of 62 vessels totaling 350,000 gross tons; only 2 amounting to 218 gross tons were built for firms outside the Kawasaki Dockyard group. By 1926, the company was, in effect, completely excluded from Japan's merchant ship market.

It is not completely clear why Kawasaki fell into this situation, but at least the following two factors seem to have had a significant influence on its destiny. First, during the war Japan's shipping firms began to take control of shipbuilding companies by acquiring their stock. Second, Kawasaki Dockyard moved in a direction quite contrary to this trend.

Throughout the war shipping firms worked to strengthen their relationships with shipbuilding firms. As early as 1914 Osaka Shosen

Table 2 Customers of Kawasaki Dockyard

(gross tons, \%)

$1919-1926$

$1927-1931$

\begin{tabular}{|c|c|c|c|c|c|}
\hline Kawasaki Dockyard & (54) & 314,172 & [89.8] & & -- \\
\hline Kawasaki Kisen & (1) & 5,950 & {$[1.7]$} & & -- \\
\hline Kokusai Kisen & & -- & & (1) & $5,959[26.6]$ \\
\hline Japanese Government & & --- & & (5) & $8,698[38.9]$ \\
\hline U.S. Government & (5) & 29,615 & {$[8.4]$} & & -- \\
\hline Others & (2) & 218 & {$[0.1]$} & (3) & $7,734[34.5]$ \\
\hline Total & $(62)$ & 349,955 & {$[100.0]$} & (9) & $22,391[100.0]$ \\
\hline
\end{tabular}

Note: Only ships over 100 gross tons are taken into account. 2) Stock boats invested in Kawasaki Kisen and Kokusai Kisen are included under Kawasaki Dockyard. 3) Figures in parentheses are numbers of ships; those in square brackets are percentage accounted for by each customer.

Source: Kawasaki Jukogyo Kabushiki Kaisha Shashi: Nenpyo, Shohyo (The History of Kawasaki Dockyard Company: Chronological Tables and Statistics), 1959, pp. 162-202. 
(O.S.K., Japan's second largest ocean-going liner operator) persuaded its men to purchase shares in Osaka Tekko Sho (Osaka Iron Works), in a move to participate in the shipbuilding company's management.3) Yamashita Kisen (Yamashita Steamship) joined the management of Uraga Dock Company in 1917.4) That same year, Nihon Yusen (N.Y.K., Japan's largest ocean-going liner operator) purchased shares of Yokohama Dock Company, turning it into a subsidiary.5) As seen in these examples, the virtual acquisition of shipbuilding firms by shipping firms was an industry-wide trend which markedly transformed the shipbuilding industry's market structure.

Following this development, shipping companies began ordering ships mostly from affiliated shipbuilders. ${ }^{6)}$ Thus, for example, Osaka Shosen ordered half of the ships it needed from Osaka Tekko Sho before 1922. Yamashita Kisen ordered many ships from Uraga Dock. ${ }^{7)}$ Despite this trend, Kawasaki Dockyard not only made no effort to form relationships with shipping companies; it made a decision which irritated them. The wartime shipping boom led to rapid expansion in demand for ships. Kawasaki, however, refused to accept orders for custom-built ships and turned instead to mass-production of identical ready-made ships, called "stock boats," on which it earned a huge profit of over 90 million yen. ${ }^{8}$ ) Shipping companies saw this as a move against their own interests, and responded accordingly. When, for example, Kawasaki refused to build vessels to Osaka Shosen's specifications, Osaka Shosen decided to order no more ships from Kawasaki.9)

This, moreover, was not the only way in which Kawasaki offended the shipping companies. Another irritant was the company's decision to go into the shipping business itself. We shall take up this point again later.

In contrast to Kawasaki, whose policies led to exclusion from the merchantship market, Mitsubishi maintained a stable relationship with shipping companies. As shown in Table 3, the company depended heavily for orders on two major shipping companies, Nihon Yusen and Osaka Shosen.

Nonetheless, Mitsubishi too suffered heavily from changes in its customers' policies. From 1919 to 1926, Nihon Yusen purchased 35 ships totaling 214,000 gross tons. ${ }^{10)}$ Of these, 15 , amounting to 104,000 gross tons, were built by Mitsubishi. In tonnage, these vessels accounted for slightly less than half of Nihon Yusen's purchases.

Before the war, $43.7 \%$ of Nihon Yusen's vessels were built by Mitsubishi, so it would seem that Mitsubishi had actually improved its share of Nihon Yusen's orders.11) In fact, however, the post-war figures in- 
clude some vessels ordered in 1918, some originally ordered by other companies and later taken over by Nihon Yusen, and stock boats built by Mitsubishi during the war. When these are excluded, we find that Nihon Yusen actually ordered only 7 vessels totaling 50,000 gross tons from Mitsubishi.12) Between 1919 and 1923 Nihon Yusen ordered 10 vessels totaling 55,000 gross tons from its subsidiary Yokohama Dock, and for several years after 1923 it continued to place orders, albeit for small vessels, with Yokohama, while placing no orders with Mitsubishi.13) It is clear, then, that Nihon Yusen treated its subsidiary more favorably than it did Mitsubishi Shipbuilding.

Turning now to Mitsubishi's relationship with its other largest customer, Osaka Shosen, we find that here again Mitsubishi received fewer orders than Osaka Shosen's subsidiary, Osaka Tekko Sho. As shown in Table 3, from 1919 to 1926 Mitsubishi built 15 ships totaling 73,000 gross tons for Osaka Shosen. These orders did not, however, form a continuous steady stream, but instead were bunched between 1919 and 1921 and in 1925 and 1926. During the first of these periods, Osaka Shosen purchased 25 vessels totaling 123,000 gross tons, of which Mitsubishi built only 6 vessels amounting to 43,000 gross tons, receiving only $35 \%$ of Osaka Shosen's order.14) 17 of the remaining 19 were built by Osaka Tekko Sho.15)

Ship repair is another important source of revenue for shipbuilding companies, and here too, as shown in Table 4, Mitsubishi surpassed Kawasaki. Kawasaki's repair business declined steadily after 1919, when it reached a record 531,000 gross tons. The one exception was 1924 , when it briefly returned to its pre-war level.

In contrast, Mitsubishi's repair business remained stable, except for a downturn in 1921. These results reflect the company's efforts to improve its repair facilities. From its founding, Mitsubishi Shipbuilding had modern repair facilities at its Nagasaki Works. To meet increasing demand, additional facilities were added at the Kobe Works, at what was then Japan's largest harbor: a first dock in 1905, when the Works were accomplished, a second in 1908 and a third in 1919. The company also built its Hikoshima Works with repair facilities for fishing boats in Shimonoseki, the center of the fishing industry in western Japan.16) Superior repair facilities in favorable locations gave Mitsubishi an important advantage over its rivals.

Kawasaki was in a weaker position than Mitsubishi in both commercial shipbuilding and ship repair. If Kawasaki seemed outwardly as prosperous as its rival, the reason was a larger volume of business constructing military vessels for the Japanese Navy. As seen in Table 5, from 
Nihon Yusen

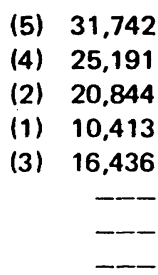

(15) 104,626

[41.1]

Sub-total

1927

1928

1929

1930

1931

Sub-total

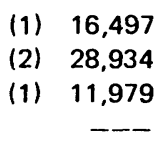

(4) 57,860
Osaka Shosen
(3) 18,528
(2) 19,391
(1) 5,243
(1) 688
(1) 697
(3) 15,231
(4) 13,061

(15) 72,839 [28.6] [27.6]

(3) 9,825

(2) 19,253

(4) 33,452

(1) 6,386

(10) 68,916 [32.8]
Others



(3) 857

(36) 76,992 [30.3]
(7) 21,196
(5) 24,298
(3) 10,694
(6) 12,494
(8) 14,581
(29) 82,263 [39.6]

Total

Fishing Boats

(10) 61,816

(13) 65,035

(6) 44,449

(3) 17,651

(13) 23,683

(5) 8,204

(9) 19,701

(7) 13,918

(66) 254,457

[100]
(7) 21,196
(9) 51,070
(7) 58,881
(11) 57,925
(9) 20,967

(43) 210,039

[100]

$\begin{array}{rc}(2) & 450 \\ & --- \\ (3) & 736 \\ (2) & 550 \\ (7) & 353 \\ (12) & 640 \\ (2) & 290 \\ (15) & 772\end{array}$

(53) 3,791

(7) 1,008

(7) 635

(14) 1,662

(15) 2,943

(7) 683

(50) $\quad 6,931$

Notes: 1) Only ships over 100 tons are included; except for fishing boats over 10 tons. 2) Figures in parentheses are numbers of ships; those in square brackets are the percentage accounted for by each customer.

Source: Mitsubishi Zosen Kabushiki Kaisha, Sogyo 100 Nen no Nagasaki Zosen Sho (100 Years of Nagasaki Shipyard), 1957. pp. 522-563: Shin Mitsubishi Jukogyo Kabushiki Kaisha, Shin Mitsubishi Kobe Zosen Sho 50 Nenshi (50-Year History of Shin Mitsubishi Kobe Shipyard), 1957. Supplement, pp. 11-13; Shimonoseki Zosen Sho 50 Nenshi (50-Year History of Shimonoseki Shipyard), 1964, pp. 246-263. 
Table 4 Ships Repaired by Mitsubishi and Kawasaki

$(1,000$ gross tons $)$

\begin{tabular}{lrrrr} 
& \multicolumn{2}{l}{ Mitsubishi } & \multicolumn{2}{l}{ Kawasaki } \\
1913 & $(381)$ & 690 & $(127)$ & 289 \\
1914 & $(347)$ & 852 & $(91)$ & 221 \\
1915 & $(421)$ & 708 & $(76)$ & 197 \\
1916 & $(539)$ & 1,073 & $(93)$ & 283 \\
1917 & $(461)$ & 1,078 & $(85)$ & 304 \\
1918 & $(467)$ & 1,042 & $(109)$ & 395 \\
1919 & $(513)$ & 1,326 & $(111)$ & 531 \\
1920 & $(505)$ & 1,257 & $(89)$ & 348 \\
1921 & $(434)$ & 918 & $(64)$ & 247 \\
1922 & $(613)$ & 1,347 & $(74)$ & 281 \\
1923 & $(610)$ & 1,250 & $(64)$ & 264 \\
1924 & $(689)$ & 1,570 & $(108)$ & 421 \\
1925 & $(569)$ & 1,159 & $(84)$ & 257
\end{tabular}

Note: Figures in parentheses are numbers of ships.

Source: Annual Report of Mitsubishi \& Co. for 1913-1925: Kawasaki Jukogyo Kabushiki Kaisha Shashi, p. 136.

1919 to 1926 Kawasaki built 35 military vessels totaling 165,000 displacement tons, while Mitsubishi built 37 totaling 116,000 displacement tons.

In terms of tonnage, Kawasaki's business was 1.4 times larger than Mitsubishi's, but this apparent advantage had little significance. For the most part it reflected construction of "special service vessels" which

Table 5 Naval Vessels Built by Mitsubishi and Kawasaki

(displacement tons)

Mitsubishi

Battleships
Cruisers
Destroyers
Submarines
Gunboats
Special Service Vessels
Submarine Depot Ships
Total

(1) 39,900

(6) 34,765

(7) 8,615

(18) $\quad 16,917$

(2) 610

(1) 5,566

(2) $\quad 10,320$

(37) 116,693
Kawasaki

$\begin{array}{rr}\text { (1) } & 39,900 \\ (5) & 29,665 \\ (8) & 6,260 \\ \text { (15) } & 14,964 \\ & - \\ \text { (6) } & 74,350 \\ & --- \\ \text { (35) } & 165,139\end{array}$

Source: Nihon Kinsei Zosen-shi: Taisho Jidai, pp. 52-59; Showa Zosenshi, pp. 776-797, 818-834. 
did not materially help the company's business performance. Building fighting ships was more profitable, and in this field Mitsubishi had the lead.

Of the military vessels built by Kawasaki, the most profitable were destroyers, followed by cruisers, special service vessels and submarines. But in terms of profit per ton, the special service vessels were only one-seventh as profitable as the submarines, themselves the least profitable of the three types of fighting ships the company produced (Table 6). Comparable figures are not available for Mitsubishi, but we may surmise that its return from the various types of military vessels was not substantially different from Kawasaki's. We can conclude, then, that Mitsubishi enjoyed an extra advantage by avoiding the less profitable special service vessels and concentrating on fighting ships instead.

Table 6 Profits from Building Naval Vessels at Kawasaki Dockyard

\begin{tabular}{lrrrrrr} 
& & & & \multicolumn{2}{c}{$\begin{array}{c}\text { Special } \\
\text { Service }\end{array}$} & (yen, \%) \\
& Cruisers & Destroyers & Submarines & Vessels & Total \\
Price to & $52,836,115$ & $17,587,952$ & $36,012,614$ & $16,216,301$ & $122,652,982$ \\
Navy & & & & & \\
Total Cost & $44,679,205$ & $14,266,740$ & $34,513,935$ & $15,143,906$ & $108,603,786$ \\
Profit & $8,156,910$ & $3,321,212$ & $1,498,679$ & $1,072,395$ & $14,049,196$ \\
Profit Ratio & 58.1 & 23.6 & 10.7 & 7.6 & 100 \\
Profit/ton & 274 & 530 & 100 & 14 &
\end{tabular}

Source: Papers at Kawasaki Jukogyo Kabushiki Kaisha.

\section{The Effects of Different Business Policies}

Kawasaki Dockyard was No. 1 in naval shipbuilding through the early part of the 1920's. During this period 166 military vessels totaling 580,000 displacement tons were built in Japan, and Kawasaki had $28 \%$ of this market compared to Mitsubishi's 20\%.17) Including vessels built by the Japanese Naval Dockyard this accounts for $81 \%$ of all military vessels built in this period.18) Why then was the company's overall situation poor?

The answer lies in financial problems caused by the company's decision to get into the shipping industry as well as shipbuilding just before the end of the war. Getting into shipping business tied up a huge quantity of capital and caused severe financial strain during the post-war business slump. The company's problems were compounded by its efforts to overcome the slump by expanding its business, a policy which 
led to a deadlock around 1925 .

For a short time after the war, Mitsubishi also attempted to expand its business. Further, as shown in Table 7, the company again increased its investment in plant in 1920, following a sharp cut the previous year. The company's decision to expand was clearly a response to the plans of the Japanese Navy, which wanted to have a huge fleet with 8 battleships, 8 cruisers and a host of smaller vessels. To reach this goal, it planned to build 120 vessels in all, including 4 new battleships and cruisers. 19) To build this " 8.8 " fleet would require additional shipbuilding facilities, and the shipbuilders agreed to expand their yards in anticipation of large Navy orders. ${ }^{20)}$

In addition to acceding to the Navy's request to enlarge its facilities, Mitsubishi also attempted to diversify its business. At one time the company planned to spend $36 \%$ of its total plant investment budget on enterprises other than shipbuilding, but in fact it proceeded very cautiously. It had, for example, acquired a large lot in 1918, intended as the site for expanding its electrical machinery business. However, when the war ended, it canceled plans for adding new large-scale factories.21) This policy shift is reflected in Table 7 which shows drastic reductions in investments in non-shipbuilding divisions after 1920. On the other hand, Mitsubishi continued to invest heavily in its Nagasaki Works, its main yard for naval construction, with funds on a massive scale beginning in the second half of 1918.22) By 1921 the company's combined investments on its

Table 7 Plant Investments of Mitsubishi Shipbuilding

$\begin{array}{lllll}\begin{array}{l}\text { Nagasaki } \\ \text { Works }\end{array} & \begin{array}{l}\text { Kobe } \\ \text { Works }\end{array} & \begin{array}{l}\text { Hikoshima } \\ \text { Works }\end{array} & \begin{array}{l}\text { Nagasaki } \\ \text { Arms Works }\end{array} & \text { Others }\end{array}$ Total

$\begin{array}{rrrrrrr}1912 & 757 & 264 & -- & -- & -- & 1,021 \\ 1913 & 668 & 249 & --- & -- & -- & 917 \\ 1914 & 659 & 196 & 243 & -- & -- & 1,098 \\ 1915 & 1,203 & 544 & 53 & -- & -- & 1,800 \\ 1916 & 768 & 972 & 55 & 928 & -- & 2,723 \\ 1917 & 2,208 & 4,980 & 664 & 154 & -- & 8,006 \\ 1918 & 5,547 & 8.085 & 519 & 302 & 4,171 & 18,624 \\ 1919 & 1,253 & 1,700 & 453 & 626 & 2,220 & 6,252 \\ 1920 & 5,181 & 1,416 & 557 & 3,016 & 344 & 10,514 \\ 1921 & 1,541 & 1434 & 67 & 3 & 18 & 3,063 \\ 1922 & 659 & 356 & 125 & 64 & -- & 1,204 \\ 1923 & 327 & 285 & 41 & 1,354 & -- & 2,007 \\ 1924 & 414 & 351 & 83 & 543 & -- & 1,391 \\ 1925 & 551 & 354 & 35 & 723 & -- & 1,663\end{array}$

Source: Annual Report of Mitsubishi \& Co., 1912-1925. 
Nagasaki Works, Nagasaki Arms Works and Nagasaki Steel Works reached $20,500,000$ yen, which accounted for $66 \%$ of its total investments during the same period.23)

Massive as they were, however, Mitsubishi's investments were moderate compared to those of Kawasaki Dockyard. From 1919 to 1921 Kawasaki is estimated to have spent $100,000,000$ yen. One of the reasons the company had to spend so much was its going into the shipping business. During the war the company had mass-produced "stock boats" which it operated until they were sold. This strategy had reaped large profits, so after the war the company decided to go into shipping business on a larger scale. 24 )

The president of Kawasaki Dockyard at that time was Kojiro Matsukata, an active entrepreneur with his own ideas about shipping business. It was under his leadership that Kawasaki's grandiose business strategy was formulated.25) According to this plan, Kawasaki would build a large number of vessels, allocate them to various ocean lines and establish a worldwide shipping network.

So despite the depression affecting both shipbuilding and shipping, Kawasaki forged ahead, ordering ships built for its own use. It established an operating subsidiary, Kawasaki Kisen (Kawasaki Shipping Company), joined in the formation of Kokusai Kisen (International Steamship Company), and organized a huge shipping conglomerate.26) No accurate records exist, but carrying out these plans must have required huge sums of money. One clue is the company's annual report for the second half of 1921, which shows the aggregate book value of ships the company owned and stock accepted in exchange for investment in kind as worth approximately 88 million yen. ${ }^{27)}$

During the same period, Kawasaki Dockyard was also investing heavily in shipbuilding facilities in response to the Japanese Navy's request. The company's direct investment in this area was estimated at about 10,000,000 yen.28) The company also invested in steel works to supply raw materials for its shipyards, and the total amount of its investment directly or indirectly related to the Navy's expansion plan was estimated as 22.5 million yen.29) Adding this amount to the company's in the shipping business, Kawasaki's total investment comes to around 110 million yen.

As a result of this aggressive strategy, Kawasaki soon became heavily dependent on outside funding. It is true that the company earned wartime profits and held huge reserves amounting to nearly $45,000,000$ yen in one financial term, the second half of fiscal 1919.30) But even before the end of the war, it had started to increase its short-term in- 
debtedness in the form of notes payable. ${ }^{31)}$ For a while the company's financial situation stabilized because it acquired huge amounts of money through the manipulation concerning the establishment of Kokusai Kisen.32) However, in 1921 the amount of notes payable outstanding was double the level of the prewar period.33) As business slumped, Kawasaki Dockyard became so desperately in need of funds that it was even forced to ask its shareholders to settle unpaid shares twice in a single month.

In contrast to Kawasaki's dependence on outside funding, Mitsubishi Shipbuilding had enough reserves to see it through the hard times ahead, even though its wartime profits had been relatively small and its reserves in the second half of 1919 were only about $12,000,000$ yen, only a little more than a fourth of Kawasaki's in the same period.34) Mitsubishi Shipbuilding was originally established by splitting off from Mitsubishi Goshi Kaisha,35) and started out with huge liquid assets.36) In addition, its post-war investments were far smaller than Kawasaki's, making it unnecessary to depend on external funding.

As I have mentioned above, the main source of revenue for both Kawasaki and Mitsubishi Shipbuilding was building military vessels for the Japanese Navy. Following the sharp post-war downturn in commercial shipbuilding, building new ships for the Navy was essential for both companies' continued prosperity.

This hope, however, was dashed by the Washington Disarmament Agreement in 1922. It was a blow perfectly timed to knock out the Japanese shipbuilding industry completely.

Both Kawasaki and Mitsubishi had made huge investments in new facilities for naval ship construction, and the Navy had, in fact, placed large orders with both companies. In the case of Mitsubishi Shipbuilding, the battleship Tosa (39,900 displacement tons) had already been launched in 1921. The 41,200-ton battle cruiser Takao was under construction. At Kawasaki, a battleship with the same tonnage as the Tosa was nearly completed and construction of the Takao-type battle cruiser Atago was about to begin. The Washington Agreement included destruction of all four of these mammoth vessels, and the Navy duly ordered the companies to stop building them. Five submarines ordered from Kawasaki were also canceled. ${ }^{37)}$

Disarmament had a severe impact throughout Japan's shipbuilding industry, but posed especially serious problems for Kawasaki and Mitsubishi. Their problems were two-fold: finances and excess capacity. But here again the two companies moved in opposite directions.

It was Kawasaki Dockyard that first came under severe financial 
pressure. Following the Disarmament Agreement, the Navy decided to settle its accounts with the shipbuilding companies by transfering advanced payment for stopped and canceled vessels to the newly contracted vessels. Any balance left over would be deducted from future contracts. Following this decision the Navy transferred advanced payment totaling $19,000,000$ yen to Kawasaki Dockyard. ${ }^{38)}$ This form of settlement meant, however, that for a while there was no ongoing flow of money from the Navy to Kawasaki, causing a shortage of working capital. As a result, from the second half of 1921 to the first half of 1922, Kawasaki's notes payable increased from 20,000,000 yen to $34,000,000$ yen. ${ }^{39)}$ Mitsubishi Shipbuilding faced a similar situation, but because of the company's sound financial policy, the damage was slighter.40)

Disarmament also caused a severe problem of excess capacity and employment for both companies. As shown in Table 8 , while their payrolls were declining, both had far more workers at the time of the Disarmament Agreement than they had had before the war. Most of these excess workers had been recruited for building the military vessels required for the Japanese Navy's planned 8.8 Fleet. The demise of that plan was especially difficult for Kawasaki Dockyard, which had by then excluded itself from commercial shipbuilding. There was, in fact, no reason to keep so many workers, since retaining them would be a heavy financial burden. Instead of laying them off, however, Kawasaki's

Table 8 Number of Workers Employed by Mitsubishi and Kawasaki

$$
\text { Mitsubishi }
$$

1912

1913

1914

1915

1916

1917

1918

1919

1920

1921

1922

1923

1924

1925
11,394

12,778

13,830

13,876

17,776

21,978

26,030

31,719

30,183

27,437

19,426

18,104

16,817

13,963
Kawasaki

\section{9,869}

11,676

12,977

12,504

14,341

20,351

20,274

20,091

18,671

16,181

13,386

12,456

12,556

13,124

Source: Annual Report of Mitsubishi \& Co., 1912-1925: Kawasaki Zosensho 40 Nenshi (40-Year History of Kawasaki Dockyard). 1936. 
management decided to expand its business.

Mitsubishi responded quickly to the new situation. In less than a month after the Washington Disarmament Agreement was conclude, the company discharged $10 \%$ of 30,000 workers at its Nagasaki Works and later fired 2,200 more from the same works.41) From 1922 to 1929, it also let go 729 workers at its Kobe Works.42) By taking such drastic measures, the company was able to reduce its workforce to half what it was before the Disarmament Agreement. Additional steps included the 1923 closing of its Nagasaki Steel Works, which supplied raw material to the Nagasaki Works,43) and the sale in the following year of the electric machine shop of the Nagasaki Works to Mitsubishi Denki, an affiliated company. ${ }^{44)}$

All these steps were clearly taken with an eye to rationalizing the company's business by cutting back unprofitable divisions. They resulted in the company's returning to its pre-war condition in which shipbuilding was its main activity, with ship repair and machine manufacturing as its major sidelines.

This does not mean that Mitsubishi had given up completely on diversifying its business. It continued to invest in its Nagasaki Arms Works, where steady orders for torpedoes supported rapid growth; so much so that by 1924 this division accounted for $10 \%$ of Mitsubishi Shipbuilding's working revenue. Overall, however, it pursued a policy of retrenchment, so that by the end of 1926 the company's fixed capital had decreased to $90 \%$ of its 1921 level.45)

In sharp contrast to Mitsubishi's hardnosed policy, Kawasaki was rather soft. Instead of discharging workers, it only stopped hiring new workers and waited to reduce its workforce through older workers' retirement. This policy seems to have been a mixture of President Kojiro Matsukata's paternalism and the company's desire to retain skilled workers for future expansion. ${ }^{46)}$

Anticipating Navy orders, the company had also added machine shops and other facilities to its shipyard. Instead of disposing of these excess facilities, it tried unsuccessfully to use them for other purposes. ${ }^{47)}$ A typical example of the company's inability to adapt to changes in its business environment was its failure to close its steel works, which specialized in making thick steel plate for armoring warships, even though there was no civilian market for this product.48) Another was the 1922 decision to go into manufacturing aircraft. When the Washington Agreement was concluded, production plans had nearly been completed, so the company forged ahead anyway.

Excess capacity and failure to retrench further strained the company's 
finances. To continue its expansion program, Kawasaki was forced to seek external funding. Precise plant investment figures are not available, but the total is estimated to have been around 9,000,000 yen.49) To raise these funds, Kawasaki adopted a peculiar strategy. First it would draw a bill for the sum of a loan. Then, when the total reached a certain amount, it would issue bonds, turning short-term into long-term liabilities. Paying interest on the loans and repaying the bonds required additional loans, so the company's financial position steadily worsened. Finally, it faced a financial crisis.

A look at the way the two companies allocated profits is also revealing. As shown in Table 9, Mitsubishi consistently allocated a large amount of its profits to reserves, while at Kawasaki much profit was dissipated in dividends or executive bonuses. Except in 1924, the first few years following 1922 saw Kawasaki still posting larger profits than Mitsubishi. Since, however, there was actually no way for Kawasaki to surpass its competitor, it would seem that Kawasaki's profits were largely watered.

To raise outside funds, it was necessary for Kawasaki to give the appearance of being a profitable company able to pay generous dividends. This may account for why it continued to report large profits.

At Mitsubishi profits were falling, but by limiting dividends the company was still able to accumulate reserves. Even setting aside funds allocated to employee retirement allowances, its aggregate net reserves had reached $12,000,000$ yen by the second half of 1926.50 )

\section{Conclusion}

The end of the 1920's brought a rush of new orders for Japan's shipbuilding industry. This boom resulted from new movement by the shipping industry. Trying to strengthen their competitiveness to offset the Depression, major shipping companies began to order superior diesel-powered ships to replace their old steam-powered vessels.

This changed environment brought new prosperity to Mitsubishi, which was one of Japan's most active shipbuilders. As shown in Table 1 , the company launched ships totaling more than 50,000 tons each year from 1928 to 1930 . In 1929 it captured fully 50\% of the market from its six major competitors. Since most of the ships built in this period were diesel-powered, Mitsubishi's experience in building dieselpowered military vessels gave the company many advantages.

In 1925 and 1926 Mitsubishi built three diesel-powered ships for Osaka Shosen. The first two were equipped with imported diesel engines, but the third was powered by a diesel engine built by Mitsubishi itself,51) impressive evidence of the company's accumulating technical know-how. 
Table 9 Disposal of Profits by Mitsubishi and Kawasaki

\section{Mitsubishi}

$\begin{array}{rrrrrr}\begin{array}{c}\text { Year } \\ \text { (Half) }\end{array} & \text { Profit } & \begin{array}{l}\text { Dividends } \\ \text { \& Bonus }\end{array} & \text { Reserves } & \begin{array}{l}\text { Aggregate } \\ \text { Reserves }\end{array} & \text { Profit } \\ 1919(1) & 4,176 & 3,000 & 1,000 & 1,000 & 10,307 \\ (2) & 5,745 & 3,000 & 2,800 & 3,800 & 12,186 \\ 1920(1) & 2,518 & 1,500 & 1,000 & 4,800 & 10,858 \\ (2) & 3,074 & 1,650 & 1,410 & 6,210 & 7,719 \\ 1921(1) & 3,074 & 1,920 & 1,160 & 7,370 & 3,952 \\ (2) & 2,977 & 1,620 & 1,300 & 8,670 & 3,919 \\ 1922(1) & 3,252 & 1,620 & 1,460 & 10,130 & 4,616 \\ (2) & 3,572 & 1,650 & 1,700 & 11,830 & 4,633 \\ 1923(1) & 3,173 & 1,650 & 1,100 & 12,930 & 4,583 \\ (2) & 3,184 & 1,650 & 1,300 & 14,230 & 4,295 \\ 1924(1) & 3,664 & 1,670 & 1,700 & 15,930 & 2,684 \\ (2) & 3,705 & 1,670 & 1,800 & 17,730 & 2,950 \\ 1925(1) & 2,546 & 1,670 & 850 & 18,580 & 2,921 \\ (2) & 2,281 & 1,650 & 1,150 & 19,730 & 2,869 \\ 1926(1) & 1,875 & 1,620 & 950 & 20,680 & 3,282 \\ (2) & 1,654 & 1,300 & 500 & 21,180 & 3,563 \\ 1927(1) & 1,591 & 1,300 & 350 & 21,530 & -1,834 \\ (2) & 1,745 & 1,300 & 350 & 21,880 & -33,467 \\ 1928(1) & 1,909 & 1,300 & 600 & 22,480 & 157 \\ (2) & 1,865 & 1,300 & 550 & 23,030 & -19,851 \\ 1929(1) & 1,705 & 1,300 & 450 & 23,480 & 0 \\ (2) & 1,794 & 1,300 & 400 & 23,880 & 0 \\ 1930(1) & 1,203 & 980 & 210 & 24,090 & -1,373 \\ (2) & 368 & 830 & 50 & 24,140 & -5,593 \\ 1931(1) & 221 & --- & --- & --1,689 & -4,680 \\ (2) & 74 & --- & -- & --- & -4,756\end{array}$

The financing of these ships shows an interesting relationship between Mitsubishi and Osaka Shosen. Osaka Shosen wanted the new ships but lacked the funds to purchase them, so it asked Mitsubishi to extend credit in the form of underwriting 6,500,000 yen worth of bonds issued by itself.52) Mitsubishi was able to supply funds to Osaka Shosen and to take this opportunity to develop a self-made diesel engine by using the monetary reserves and technological know-how it accumulated during the slump.

Kawasaki found itself in a miserable situation, and built only 7 ships during the whole of the new boom. It, too, had acquired experience in building diesel-powered vessels for the Navy, but its actions had alienated the shipping companies and left it excluded from the mercantile ship market. ${ }^{53)}$ In addition, its financial position declined dramati- 


\section{Kawasaki}

$\begin{array}{lrr}\begin{array}{l}\text { Dividends } \\ \text { \& Bonus }\end{array} & \text { Reserves } & \begin{array}{r}\text { Aggregat } \\ \text { Reserves }\end{array} \\ 5,264 & 5,208 & 5,028 \\ 5,690 & 5,568 & 10,596 \\ 6,940 & 3,202 & 13,798 \\ 6,940 & 772 & 14,570 \\ 3,782 & 200 & 14,770 \\ 4,923 & 196 & 14,966 \\ 4,383 & 231 & 15,197 \\ 4,383 & 232 & 15,429 \\ 4,383 & 230 & 15,659 \\ 4,378 & 215 & 15,874 \\ 2,918 & 135 & 16,009 \\ 2,918 & 148 & 16,157 \\ 2,918 & 147 & 16,304 \\ 2,946 & 144 & 16,448 \\ 3,256 & 165 & 16,613 \\ 3,285 & 179 & 16,792 \\ --- & --- & -- \\ --- & --- & --- \\ --- & --- & --- \\ --- & -- & --- \\ --- & --- & --- \\ --- & --- & --- \\ --- & --- & --- \\ --- & --- & --- \\ --- & --- & --- \\ --- & --- & ---\end{array}$

Source: Business Report of Mitsubishi Shipbuilding and Engineering Company and Business Report of Kawasaki Dockyard Company.

cally, and during the nationwide financial panic of 1927 the company failed completely.54) Before this event, Nihon Yusen had decided to build three diesel-powered ships and to order one from Kawasaki and two from Mitsubishi, but hearing news of the financial failure of Kawasaki, it canceled the order and shifted it to Yokohama Dock.55) Kawasaki lost the hope of reentering the mercantile ship market and the opportunity to build the first diesel-powered ships.

\section{Notes}

1) Takeaki Teratani, Nihon Kindai Zosenshi Josetsu (History of the Shipbuilding Industry), Gannando, 1979, p. 393.

2) This company was organized in 1919 by the investment in 11 ships 
owned by Kawasaki Dockyard. Kawasaki Kisen 50 Nenshi (50-Year History of Kawasaki Steamship), 1966, p. 33.

3) For details, see Kazuo Sugiyama, "Zosen Kinyushi no Ichikosatsu" (A Study of the Development of the Finance of Shipbuilding Industry), Kinyu Keizai (The Journal of Financial Economics), Kinyu Keizai Kenkyusho (The Institute for Banking and Financial Research Inc.) Vol. 100, 1966.

4) On this occasion, Yamashita Kisen acquired about $40 \%$ of stock issued by Uraga Dock. Nobuo Wakiyama, "Daiichiji Sekaitaisengo Fukyoki no Wagakuni Zosengyo (IV)" (Japanese Shipbuilding Industry in the Depression Era after World War I), Kaijikeizai Sangyo Kenkyujoho (Bulletin of the Institute for Maritime Economy), No. 52, pp. 18-22.

5) In 1917 Nihon Yusen accepted 30,000 newly issued shares of Yokohama Dock and turned it into a susidiary. Teratani, op. cit., pp. 349-371.

6) In a little different form, Mitsui Bussan also had shipbuilding division to supply the company with all ships used for the company's business. Mitsui Senpaku, Sogyo 80 Nenshi (80-Year History of Mitsui Shipping Company), 1958, pp. 521-550.

7) About $40 \%$ of orders Uraga Dock accepted after the war came from Yamashita Kisen. Wakiyama, op. cit., p. 22.

8) Takao Shiba, "Taishoki Kigyokeiei no Takakuteki Kakudaishiko to so no Zasetsu," (The Intention of the Diversified Expansion of Business Management in Taisho Era and its Frustration: The Case of Kawasaki Dockyard), Osaka Daigaku Keizaigaku (The Economic Review of Osaka University), Vol. 21, 1971, p. 104.

9) Haruki Watsuji, Fune no Omoide (Memories of Ships), Kobunsha, 1948, pp. 206-209.

10) Nihon Yusen, 70 Nenshi (70-Year History), 1956, pp. 158-159.

11) Yasuo Mishima, ed., Mitsubishi Zaibatsu (Mitsubishi Zaibatsu: Series of Business Histories of the Japanese Zaibatsu), Nihon Keizai Shinbunsha, 1981, p. 336.

12) Nihon Yusen, op. cit., pp. 158-159.

13) Ibid., pp. 158-159.

14) Osaka Shosen Kabushiki Kaisha, 50 Nenshi (50-Year History of O.S.K.) 1934, pp. 409-415.

15) Ibid., pp. 409-415.

16) Mishima, op. cit., pp. 201-204.

17) Computed from Nihon Kinsei Zosenshi: Taisho Jidai (The Modern History of Japanese Shipbuilding Industry: Taisho Era), 1935, 
pp. 52-59; Showa Zosenshi. (The History of the Shipbuilding Industry in Showa Era), 1977, pp. 776-792, 818-843.

18) The number of battleships built at the Navy Shipyard in the same period was 54 (192.480 displacement tons), ibid.

19) Eiichi Kaneko, Zosen (Shipbuilding), Kojunsha, 1964, p. 206.

20) Kaigun Daijin Kanbo, ed., Kaigun Gunbi Enkaku (Changes in Armament of the Navy), Gannando, 1969, p. 121.

21) Mitsubishi Denki Shashi (The History of Mitsubishi Electric Corporation), 1981, p. 17.

22) The Second Business Report of Mitsubishi Zosen, p. 6.

23) The amount of investment in the second half of 1918 was about 11.1 milion yen in which 7.4 milion yen was for the facilities at Nagasaki. The Annual Report of Mitsubishi \& Company for 1918.

24) Shiba, op. cit., p. 111.

25) Ibid., pp. 111-117.

26) Kawasaki Kisen, Kokusai Kisen and the Shipping Division of Kawasaki Dockyard joined together to form so called $\mathrm{K}$ Line for ocean lines. They had 101 ships (504,000 gross tons) and became the second largest enterprise next to Nihon Yusen. Kawasaki Kisen 50 Nenshi; p. 47.

27) The 51st Business Report of Kawasaki Dockyard Company.

28) Papers at Kawasaki Jukogyo Kabushiki Kaisha.

29) Computed from the 45th-50th Business Report of Kawasaki Dockyard Company and Kawasaki Zosensho, The Minutes of the 52nd General Meeting of Stockholders.

30) The 47th Business Report of Kawasaki Dockyard Company.

31) The 46th Business Report of Kawasaki Dockyard Company.

32) For the details of the process of the formation of Kokusai Kisen, see Shiba, op. cit., pp. 113-116.

33) The 48th Business Report of Kawasaki Dockyard Company.

34) The 4th Business Report of Mitsubishi Shipbuilding and Engineering Company.

35) By that time Mitsubishi Shipbuilding was operating as the shipbuilding division of Mitsubishi Goshi Kaisha (Mitsubishi Limited Partnership, Mitsubishi \& Co.).

36) When Mitsubishi Shipbuilding became an independent business unit, it had about 31.3 milion yen in the form of either cash or deposit. The 1st Business Report of Mitsubishi Shipbuilding and Engineering Company.

37) The 52nd Business Report of Kawasaki Dockyard Company.

38) From this amount, 3 milion yen was to be used for advance pay- 
ments to contract in future. The 53rd Business Report of Kawasaki Dockyard Company.

39) The 51st-52nd Business Report of Kawasaki Dockyard Company.

40) Papers at Mitsubishi Jukogyo Kabushiki Kaisha

41) Mitsubishi Nagasaki Zosenshoshi: Zoku (The History of Mitsubishi Nagasaki Shipyard II), 1951, p. 37.

42) Shin Mitsubishi Kobe Zosensho 50 Nenshi (50-Year History of Shin Mitsubishi Kobe Shipyard), 1957, p. 21.

43) Mitsubishi Jukogyo Kabushiki Kaisha Shashi (The History of Mitsubishi Heavy-Industry), 1956, pp. 290-292.

44) Mitsubishi Denki Shashi, p. 25.

45) The 8th and 18th Business Report of Mitsubishi Shipbuilding and Engineering Company.

46) Shiba, op. cit., p. 127.

47) The 53rd Business Report of Kawasaki Dockyard Company.

48) Kawasaki Jukogyo Kabushiki Kaisha Shashi, p. 912.

49) Takao Shiba, "Kinyukyokoki ni okeru Keieisenryaku no Hatan to so no Seiri," (The Collapse of Business Strategy and its Settlement in the Monetary Crisis), Keiei Shigaku (Japan Business History Review), Vol. 15, No. 1, 1980, pp. 33-34.

50) The 5th-18th Business Report of Mitsubishi Shipbuilding and Engineering Company.

51) Mitsubishi Jukogyo Kabushiki Kaisha Shashi, p. 450, 527.

52) Osaka Shosen Kabushiki Kaisha 80 Nenshi (80-Year History of O.S.K.), 1966, p. 514.

53) Kawasaki Jukogyo Kabushiki Kaisha Shashi, pp. 382-388.

54) See Shiba, "Kinyu Kyokoji ni okeru Keieisenryaku no Hatan to so no Seiri."

55) Kazuo Sugiyama, Kaiungyo to Kinyu (Shipping and Finance: Fund Raising in a Depression), Nihon Keizai Shinbunsha, 1981, pp. 140142.

Translated by Kesaji Kobayashi Ryukoku University and John L. McCreery 